\title{
3D-bioprinted tracheal reconstruction: an overview
}

\author{
Lidia Frejo ${ }^{1,2}$ and Daniel A. Grande ${ }^{1,3^{*}}$
}

\begin{abstract}
Congenital tracheomalacia and tracheal stenosis are commonly seen in premature infants. In adulthood, are typically related with chronic obstructive pulmonary disease, and can occur secondarily from tracheostomy, prolong intubation, trauma, infection and tumors. Both conditions are life-threatening when not managed properly. There are still some surgical limitations for certain pathologies, however tissue engineering is a promising approach to treat massive airway dysfunctions. 3D-bioprinting have contributed to current preclinical and clinical efforts in airway reconstruction. Several strategies have been used to overcome the difficulty of airway reconstruction such as scaffold materials, construct designs, cellular types, biologic components, hydrogels and animal models used in tracheal reconstruction. Nevertheless, additional long-term in vivo studies need to be performed to assess the efficacy and safety of tissue-engineered tracheal grafts in terms of mechanical properties, behavior and, the possibility of further stenosis development.

Keywords: 3D-bioprinting, Tracheal reconstruction, Biomaterials
\end{abstract}

\section{Background}

Tracheomalacia is defined as a soft cartilaginous sustenance of the trachea which can lead to the collapse and narrowing of the airway lumen during expiration. Tracheal stenosis is a rare condition where there is a narrowing of the trachea that causes breathing problems. Congenital forms of tracheomalacia and tracheal stenosis are more commonly seen in premature infants and are associated with severe symptoms (Kugler \& Stanzel, 2014). Adult malacia and stenosis are typically related with chronic obstructive pulmonary disease, and can occur secondarily from tracheostomy, tumors, infection, prolonged intubation, trauma, and from external compression by vascular structures (Chan et al., 2019). Both conditions are life-threatening for the patients (Chan et al., 2019; Wain Jr., 2009). In mild-to-moderate tracheomalacia, observation or continuous positive airway pressure therapy might be effective; yet, if these fail and the malacia is severe, surgery is frequently indicated (Carden et al., 2005). Tracheal resection and re-anastomosis have

\footnotetext{
* Correspondence: DGrande@northwell.edu

'Orthopaedic Research Laboratory, The Feinstein Institutes for Medical

Research, 350 Community Drive, Manhasset, NY 11030, USA

${ }^{3}$ Donald and Barbara Zucker School of Medicine at Hofstra/Northwell,

Hempstead, New York, USA

Full list of author information is available at the end of the article
}

existed as a solution since late nineteenth century, but it was contraindicated for stenotic segments longer than 5 $\mathrm{cm}$ in adults and $2 \mathrm{~cm}$ in children for the risk of excess tension (Ho \& Koltai, 2008). Recently, slide tracheoplasty has improved outcomes significantly for inoperable patients (Wang et al., 2016; Basta et al., 2015). However, performing such a procedure comes at a sacrifice of tracheal length for tracheal inner diameter.

An innovative solution to overcoming these difficulties is the usage of artificial substitutes to replace long-segment narrowed trachea. Several studies have turned to grafting technologies to overcome the clinical needs facing tracheal repair. Nevertheless, donor-site morbidity, erosion, infection, the requirement of immunosuppression in a cancer patient, as well as exceedingly complex laboratory and surgical techniques have prevented widespread clinical use (Fabre et al., 2013; Crowley et al., 2015; Friedman \& Mayer, 1992; Propst et al., 2011).

Tissue engineering is a promising approach to treat massive airway dysfunctions such as tracheomalacia or stenosis. With advances in 3D-printing techniques, many studies have combined the two in order to improve the technologies that are available for tracheal surgeries. Tissue engineering and 3D-printing techniques it is possible to design a customized tracheal model with a

(C) The Author(s). 2019 Open Access This article is distributed under the terms of the Creative Commons Attribution 4.0 International License (http://creativecommons.org/licenses/by/4.0/), which permits unrestricted use, distribution, and 
morphology that is suitable for the patient and that supports the force to maintain the tissue engineered trachea (TET) shape (Sing et al., 2017). The ideal combination of tissue engineering with 3D-printing should be biocompatible, biodegradable (having an appropriate degradation rate), non-immunogenic, non-toxic, with low cost, readily available, have an appropriate degradation rate and a long shelf life (Law et al., 2016).

Bioprinting is at the vertex of the latest technological advances in 3D printing technologies. This specialty merges electronics (scanners, printers) and biology (organismal/architectural, cellular, protein/ compounds) in order to restore form and/or function in injury or disease and is considered a type of bioelectronic medicine. This field is rapidly advancing and herein we focus on the construct design, type of material, use of cells, type of species studied, method of analysis and the need of extended in vivo test (Fig. 1).

\section{Main text \\ Scaffold material}

Several authors have previously used a variety of nonresorbable biomaterials in different experimental models. A main concern with non-resorbable biomaterials is their potential for inducing a chronic inflammatory response with granulation tissue and extrusion (Yener et al., 2010; Daneshi et al., 2010; Gaafar et al., 2008). On the contrary, resorbable biomaterials, like different thermoplastic polymers: polyglycolic acid (PGA), poly(lactic-co-glycolic) acid (PLGA), polylactic acid (PLA), and poly- $\varepsilon$-caprolactone (PCL) used in 3D printing have similar properties to the tracheal cartilage; consequently, various attempts are being made to apply these materials to artificial trachea research (Chang et al., 2014).

PLA was one of the most popular materials used in 3D printing because it is already approved by the Food and Drug Administration for various uses (Athanasiou et al., 1996). Its mechanical properties help maintain the structure of the construct (Goldstein et al., 2015). PGA fibers usage in tracheal replacement was first reported in 1994 (Vacanti et al., 1994). Both PGA and PLGA have been typically used in engineered tracheal scaffold because of their high porosity, which can induce cell infiltration and neovascularization and can be absorbed at a relatively accurate time. However, due to its short absorption time and inadequate mechanical strength, it has been difficult to use for long-term therapeutic effect (Kojima et al., 2002; Rotter et al., 2005; Wu et al., 2007). Other studies have used mixtures of PLA-PGA (Long et al., 2001) or PLA-PLGA (Klein et al., 2005), yet the findings showed that the addition of other types of materials to PLA composites caused a decrease in the mechanical features of the composite used (Tappa et al., 2019). On the other hand, PCL has been used as a cartilage scaffold material because of its mechanical features, non-toxic degradation products, good biocompatibility and slow biodegradation. Properties such as low porosity, long absorption time and strength are superior to PGA, therefore PCL has long-term applicability. Some studies have also shown that low porosity promotes chondrogenesis (Karageorgiou \& Kaplan, 2005). Considering its comparatively low melting point, PCL is easily printed and can be used with commercial desktop 3D printers as confirmed by Kaye et al. (Kaye et al., 2019).

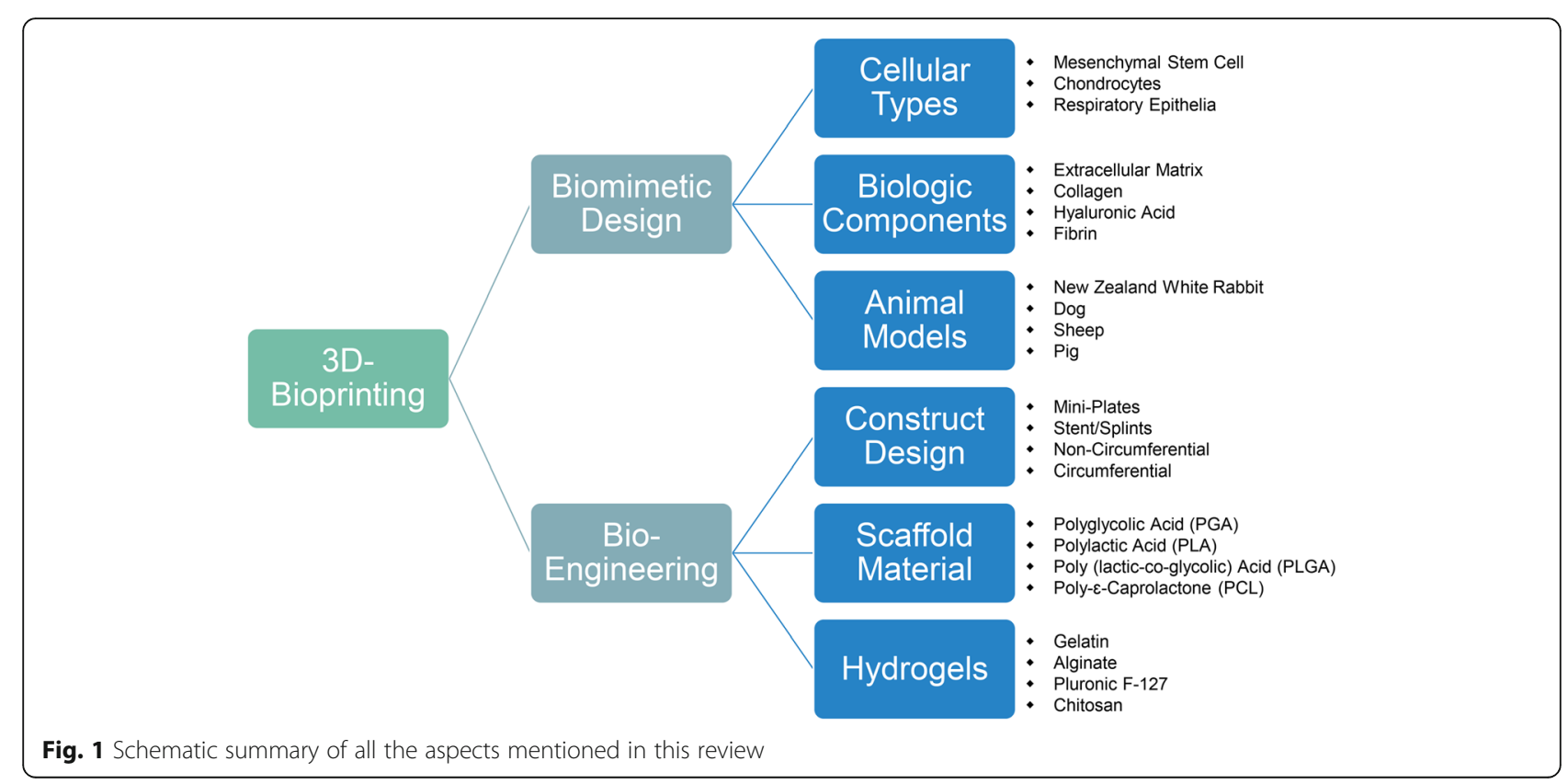




\section{Construct design}

Several repair methods have been reported in order to avoid resection and reanastomosis. We can categorize 4 extensive groups for the construct design in tracheal surgeries: a) Miniplates b) Stent/Splint c) Non-circumferential reconstruction and d) Circumferential reconstruction (Chan et al., 2019).

\section{Miniplates}

Bioabsorbable miniplates have been used safely as an alternative to autologous cartilage grafts for single stage laryngotracheal reconstruction (LTR) (Sprecher, 2010). Sprecher reported good results performing anterior split laryngotracheoplasty on 10 patients with subglottic stenosis using a resorbable PLA miniplate to keep the cricoid expansion without cartilage grafting. All patients showed fully mucosalized tracheal wall and there were no postoperative complications (Sprecher, 2010). Javia and Zur used a commercially available resorbable miniplate as an external lateral support in 7 pediatric patients undergoing LTR surgery who had unexpected airway malacia in addition to stenosis. Six children were successfully decannulated within 3 months with no further complications (Javia \& Zur, 2012). Recently, Goldstein et al. demonstrated the effectivity of 3D-printed PLA miniplates seeded with mature chondrocytes and collagen gel implanting them successfully in New Zealand white rabbits (NZW) for a total of 12 weeks (Goldstein et al., 2015).

\section{Stent/splint}

Airway stents or splints have been widely used for the treatment of tracheobronchial pathologies since late twentieth century (Liu et al., 2011). A silicone-based TTube developed by Montgomery in the 1960's is one of the earliest airway stents (Montgomery, 1965).

Silicone and metallic stents have been the most used in treating airway diseases. However, complications including prosthesis migration, granulation formation, sputum retention, stent fracture have been reported (Martinez-Ballarin et al., 1996; Lemaire et al., 2005; Chung et al., 2008; Chin et al., 2008).

Stents made of resorbable materials have advantages over silicone and metallic stents because they degrade over time and their removal is not necessary. Biodegradable stents made of polydioxanone; a material used in sutures, has been reported recently for the relief of anastomotic stenosis. Lischke et al. reported their first clinical application in 6 post-LT patients where 5 of them were in good clinical condition after 4 years' follow-up (Lischke et al., 2011). Later, Fechner et al. reported a larger case series with a total of 11 stents (Fuehner et al., 2013).

Three-dimensional printing includes the opportunity of designing customized airway stents. Therefore, patients' computerized axial tomography (CT) scan can be used to create quality cross-section images that are then stacked to create a 3D image of the scanned trachea to build personalized TET (Do et al., 2015). PCL has become the most used biomaterial in this approach and has already moved from animal studies to human patients (Huang et al., 2016; Zopf et al., 2014; Morrison et al., 2014). Thus, Hollister et al. begun to implement design control for scaffold-based tissue engineering approaches founded on 3Dprinting (Hollister et al., 2015). Using this design, Les et al. reported 15 pediatric subjects with severe tracheobronchomalacia, receiving successfully 29 3D-printed and patient-specific splints on their trachea (Les et al., 2019).

\section{Non-circumferential reconstruction}

Different shapes and sizes are used in this approach, from small rectangular pieces to $2 \mathrm{~cm}$ long $270^{\circ}$ tracheal reconstruction. Within this group, it appears less granulation and stenosis are present. PCL has become the most used material in this approach. Various studies describing the usage of small rectangular shapes show no evidence of stenosis and minimal granulation tissue over time. Histology displays regeneration of ciliated epithelium and neuro-vascularization on luminal surface (Park et al., 2018a; Park et al., 2012; Kwon et al., 2014; Jang et al., 2014). When larger defects were created and repaired on larger animals, results are variable. Townsend et al., used 15x25mm PCL implants in sheep. The animals had to be euthanized prior to the end of the study due to respiratory distress secondary to tracheal narrowing at the reconstruction site (Townsend et al., 2018). On the other hand, Rehmani et al. reconstructed a $40 \times 16 \mathrm{~mm}$ defect in 7 pigs with a PCL implant covered with an extracellular matrix and found that 5 pigs had well-sized tracheal lumen with minimal stenosis and granulation tissue after 3 months (Rehmani et al., 2017).

\section{Circumferential reconstruction}

Circumferential reconstruction is the most difficult, with longer defects being more challenging than shorter ones since they can induce more granulation tissue causing stenosis and respiratory difficulties. Granulation formation is a common complication tracheal surgery. This process is mediated by a wide range of cellular reactions such as infection, inflammation, tissue necrosis and immunological rejection (Lee et al., 2011; Nicolli et al., 2016). The granulation and stenosis seen in the scaffold segment after transplantation might be associated to the lack of protective epithelial layer along with an inflammatory reaction. Therefore, different biologic components were added to the construct in order to accelerate cell growth and migration to minimize granulation tissue formation. 
Gao et al. 3D-printed a tracheal scaffold with biodegradable material with a chondrocyte suspension and implanted the construct in the subcutaneous tissue of nude mice to overcome the inflammatory process. To evaluate the feasibility of repairing whole segment tracheal defects, replacement surgery of rabbits' native trachea by the construct was performed (Gao et al., 2017). Lee et al. assessed the use of immunosuppressive therapy after tracheal replacement however, they resolved there were no beneficial effects (Lee et al., 2017).

\section{Cellular types, biologic components and hydrogels}

Given the development of bio-printing technology, living cells can be added to a hydrogel for printing, and cells, such as chondrocytes or respiratory epithelia which play an important role in the tracheal structure, as well as mesenchymal stem cells (MSC), can be printed together in the production of artificial tracheas (Boland et al., 2006). A wide range of natural and synthetic components have been tested to promote cartilage formation for tracheal regeneration. These materials include collagen, extracellular matrix (ECM) containing molecules from the collagen family, elastic fibers, glycosoaminoglycans (GAG) and proteoglycans, and adhesive glycoproteins, gelatin, chitosan, hyaluronic acid, alginate, fibrin glue, DegraPol, acellular cartilage tissue matrices or Pluronic F-127 (Kwon et al., 2014; Jang et al., 2014; Rosso et al., 2004) that can be used alone or combined. While naturally derived scaffolds have a countless advantage in biocompatibility and neovascularization, an implant that is only made of natural materials lacks proper mechanical features and structural integrity for tracheal reconstruction (Schwarz et al., 2012). Hence, combining a naturally derived scaffold with a synthetic polymer could be key for tissue-engineered tracheal reconstruction.

Park et al. constructed a multilayered scaffold using PCL and alginate hydrogel with auricular cartilage and nasal epithelia. The artificial tracheas were transplanted into 15 rabbits for up to 12 months. Several rabbits died from respiratory symptoms. From the surviving rabbits, narrowed tracheas due to granulation were found. Their trachea seemed to be effective in respiratory epithelia regeneration but not in cartilage formation (Park et al., 2019). Recently, Park et al., have created a tissue-engineered PCL graft by stratifying tracheal mucosa decellularized extracellular matrix (tmdECM) collagen hydrogel together with human inferior turbinate mesenchymal stromal cell (hTMSC) sheets. After 2 months, there was a complete regeneration of the luminal surface of the construct. Some granulation could be observed at the transplantation site but no severe complications were observed (Park et al., 2018b).
Chondrocytes are frequently used in tracheal tissue engineering for cartilage regeneration, but the limited supply of autologous chondrocytes and the difficulty in maintaining their phenotype during in vitro culture have thwarted their wider application. Kim et al. described a successful partial tracheal reconstruction using a fibrin/ hyaluronan hydrogel seeded with chondrocytes, but neocartilage regeneration was barely seen in their results (Kim et al., 2010).

At the same time, bone marrow MSC (bMSC), as multipotent stem cells, can differentiate into chondrogenic phenotypes with proper stimulation. Co-culture of bMSCs with chondrocytes stimulates and improves the differentiation of bMSCs when both are in the same environment. In previous studies, rabbit MSC co-cultured with chondrocytes in hydrogel constructs were found to undergo differentiation into chondrocytes (Kang et al., 2012). Liu et al. used a co-culture system to mimic the articular chondrogenic configuration in subcutaneous environments (Liu et al., 2010). Tsao et al. developed a ringshaped tracheal scaffold using either PGLA or PCL stented with silicone rod and seeded with bMSC and chondrocytes for 7 days before implantation in NZW rabbits. Analysis of the biochemical and mechanical characteristics established that the PCL scaffold with co-culture cells seeding exhibited the optimal chondrogenesis with acceptable rigidity to maintain the cylindrical shape and luminal patency (Tsao et al., 2014). Recently, Bae et al. used a similar approach co-culturing chondrogenic-differentiated bMSC and respiratory epithelial cells in one scaffold. Neocartilage formation, neo-epithelization and neovascularization could be observed (Bae et al., 2018). Chang et al. 3D-printed a 10x10mm half-pipe-shaped PCL scaffold coated with rabbit MSC seeded in human-derived fibrin and then implanted for 8 weeks. Neo-cartilage was enough to keep the scaffold shape (Chang et al., 2014).

\section{Animal models}

In the 1995, Delaere et al. developed a rabbit model for orthotopic tracheal transplantation after a period of heterotopic revascularization in the lateral thoracic fascia (Delaere et al., 1995). This animal model has become the most commonly used animal model as authors argue it is the ideal model for LTR. Rabbits have a long cervical trachea that is easily accessible and resembles a human trachea in structure and size to that of an infant. Rabbits have a more diverse genetic background compared to rodents making a better approximation to human's genetic diversity (Bosze \& Houdebine, 2010; Graur et al., 1996). They are simple to manage, extensively available, and cost-effective for interventional studies (Park et al., 2018a). Nevertheless, dog, sheep, and pig models might be better to reproduce the size of teenagers with adult sized tracheas, but these large animals are difficult to 


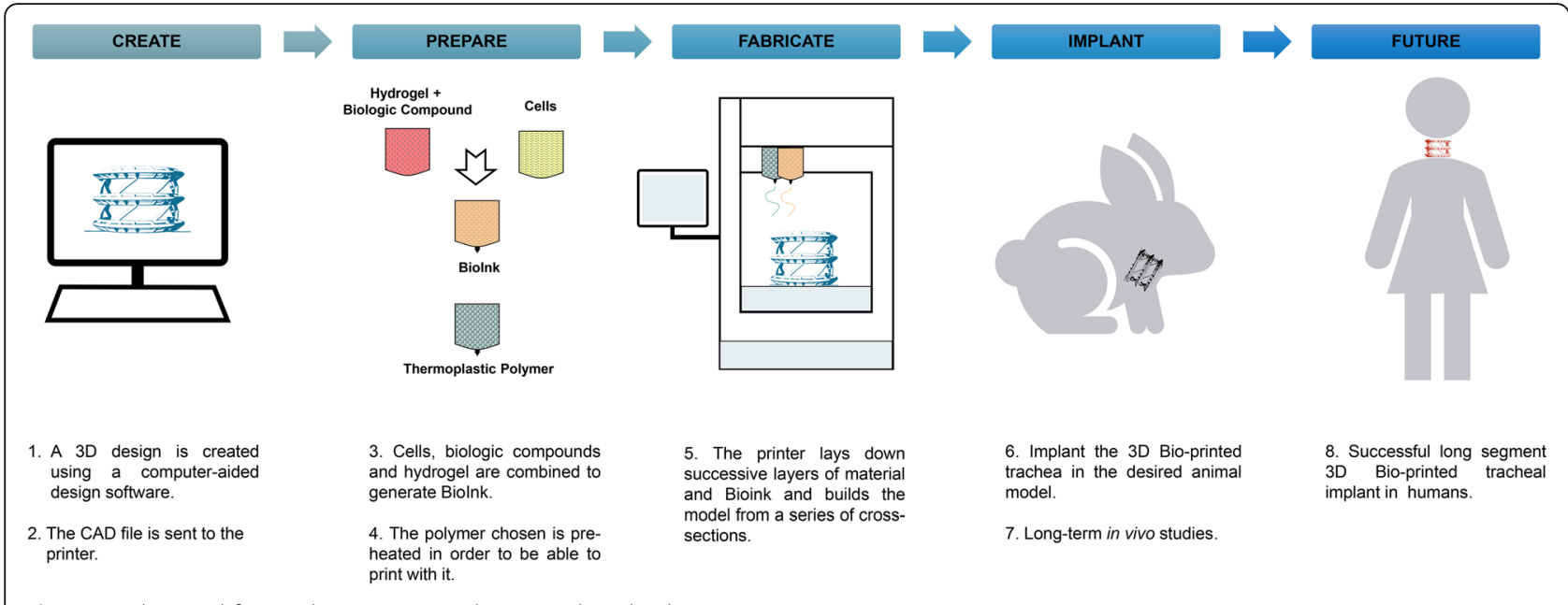

Fig. 2 Pipeline and future directions in 3D-bioprinted tracheal reconstruction

manage post-operatively and are more expensive (Zopf et al., 2014; Townsend et al., 2018; Rehmani et al., 2017).

\section{Conclusion}

Bioprinting is at the vertex of the latest technological advances in 3D printing technologies. This specialty merges biology and electronics to restore form and/or function in injury or disease (Fig. 2). In this review we surveyed the most commonly used materials, designs, cellular types, biologic components, hydrogels and animal models used in 3D-bioprinting tracheal reconstruction.

Material-wise, PCL is a rising biodegradable material that can be used for tracheal surgery. Although its usefulness on its own, the combination of PCL with cells seeded in naturally derived materials improves its effectiveness. Besides, rabbit is the most widely used animal model used in TET reconstruction as its size and shape likens the infant human trachea. Further in vivo studies need to be assessed to determine the best animal model for adult-size trachea.

Finally, additional long-term in vivo studies need to be performed to assess the efficacy and safety of the TET grafts. In order to preserve the function and enhance long-term survival and grafting rates, vascularization and epithelization of the graft need yet to be widely considered when dealing with airway reconstruction.

\section{Abbreviations \\ bMSC: Bone marrow MSC; ECM: extracelular matrix; hTMSC: human inferior turbinate mesenchymal stromal cell; LTR: laryngotracheal reconstruction; MSC: Mesenchimal Stem Cells; NZW rabbits: New Zealand White rabbits;

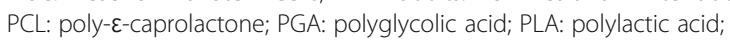 PLGA: poly(lactic-co-glycolic) acid; TET: tissue engineered trachea; tmdECM: tracheal mucosa decellularized extracellular matrix}

\section{Acknowledgements}

The authors would like to thank Sonya VanPatten for her comments on this paper.
Authors' contributions

LF drafting, final approval, accountability for all aspects of the work; DAG final approval, accountability for all aspects of the work. Both authors read and approved the final manuscript.

Funding

Not applicable.

Availability of data and materials

Not applicable.

Ethics approval and consent to participate

Not applicable.

Consent for publication

Not applicable.

\section{Competing interests}

The authors declare that they have no competing interests.

\section{Author details}

'Orthopaedic Research Laboratory, The Feinstein Institutes for Medical Research, 350 Community Drive, Manhasset, NY 11030, USA. ${ }^{2}$ Division of Otolaryngology and Communicative Disorders-Pediatric Otolaryngology, Long Island Jewish Medical Center New Hyde Park, New York, USA. ${ }^{3}$ Donald and Barbara Zucker School of Medicine at Hofstra/Northwell, Hempstead, New York, USA.

Received: 13 June 2019 Accepted: 16 August 2019

Published online: 17 September 2019

\section{References}

Athanasiou KA, Niederauer GG, Agrawal CM. Sterilization, toxicity, biocompatibility and clinical applications of polylactic acid/polyglycolic acid copolymers. Biomaterials. 1996 Jan;17(2):93-102. PubMed PMID: 8624401. Epub 1996/01/01. eng.

Bae SW, Lee KW, Park JH, Lee J, Jung CR, Yu J, et al. 3D bioprinted artificial trachea with epithelial cells and Chondrogenic-differentiated bone marrow-derived mesenchymal stem cells. Int J Mol Sci 2018 May 31; 19(6). PubMed PMID: 29857483. Pubmed Central PMCID: PMC6032277. Epub 2018/06/03. eng.

Basta MN, Mudd PA, Fuller SM, Javia LR, Taylor JA. Total airway reconstruction in the neonate: combined mandibular distraction and slide Tracheoplasty for multiple level airway obstruction. J Craniofac Surg 2015 Nov;26(8):e788-e791. PubMed PMID: 26595008. Epub 2015/11/26. eng. 
Boland T, Xu T, Damon B, Cui X. Application of inkjet printing to tissue engineering. Biotechnol J 2006 Sep;1(9):910-917. PubMed PMID: 16941443. Epub 2006/08/31. eng.

Bosze Z, Houdebine LM. Application of rabbits in biomedical research: A review; 2010.

Carden KA, Boiselle PM, Waltz DA, Ernst A. Tracheomalacia and tracheobronchomalacia in children and adults: an in-depth review. Chest. 2005;127(3):984-1005. PubMed PMID: 15764786. Epub 2005/03/15. eng.

Chan DS, Fnais N, Ibrahim I, Daniel S, Manoukian J. Exploring polycaprolactone in tracheal surgery: a scoping review of in-vivo studies. Int J Pediatr Otorhinolaryngol 2019;123:38-42. PubMed PMID: 31059931. Epub 2019/05/ 07. eng.

Chang JW, Park SA, Park JK, Choi JW, Kim YS, Shin YS, et al. Tissue-engineered tracheal reconstruction using three-dimensionally printed artificial tracheal graft: preliminary report. Artif Organs 2014 Jun;38(6):E95-E105. PubMed PMID: 24750044. Epub 2014/04/23. eng.

Chin CS, Litle V, Yun J, Weiser T, Swanson SJ. Airway stents. Ann Thorac Surg 2008 Feb;85(2):S792-S796. PubMed PMID: 18222219. Epub 2008/01/29. eng.

Chung FT, Lin SM, Chen HC, Chou CL, Yu CT, Liu CY, et al. Factors leading to tracheobronchial self-expandable metallic stent fracture. J Thorac Cardiovasc Surg 2008 Nov;136(5):1328-1335. PubMed PMID: 19026824. Epub 2008/11/26. eng.

Crowley C, Birchall M, Seifalian AM. Trachea transplantation: from laboratory to patient. J Tissue Eng Regen Med 2015 Apr;9(4):357-367. PubMed PMID: 26052583. Epub 2015/06/09. eng.

Daneshi A, Mohammadi S, Hassannia F. Delayed laryngotracheal reconstruction with titanium plate: report of 10 cases. J Voice 2010 Nov;24(6):755-757. PubMed PMID: 20083376. Epub 2010/01/20. eng.

Delaere PR, Liu ZY, Hermans R, Sciot R, Feenstra L. Experimental tracheal allograft revascularization and transplantation. J Thorac Cardiovasc Surg 1995 Sep; 110(3):728-737. PubMed PMID: 7564440. Epub 1995/09/01. eng.

Do A-V, Khorsand B, Geary SM, Salem AK. 3D Printing of Scaffolds for Tissue Regeneration Applications. Adv Healthc Mater. 2015;4(12):1742-1762. PubMed PMID: 26097108. Epub 06/10. eng.

Fabre D, Kolb F, Fadel E, Mercier O, Mussot S, Le Chevalier T, et al. Successful tracheal replacement in humans using autologous tissues: an 8-year experience. Ann Thorac Surg 2013 Oct;96(4):1146-1155. PubMed PMID: 23998399. Epub 2013/09/04. eng.

Friedman M, Mayer AD. Laryngotracheal reconstruction in adults with the sternocleidomastoid myoperiosteal flap. Ann Otolo Rhinol Laryngol 1992 Nov;101(11):897-908. PubMed PMID: 1444097. Epub 1992/11/01. eng

Fuehner T, Suhling H, Greer M, Wiesner O, Dierich M, Warnecke G, et al. Biodegradable stents after lung transplantation. Transpl Int 2013 Jul;26(7): e58-e60. PubMed PMID: 23551264. Epub 2013/04/05. eng.

Gaafar AA, El-Daly AA, Gaafar HA. Laryngotracheal augmentation using titanium mesh. J Laryngol Otol 2008 Apr;122(4):391-396. PubMed PMID: 17498337. Epub 2007/05/15. eng.

Gao M, Zhang H, Dong W, Bai J, Gao B, Xia D, et al. Tissue-engineered trachea from a 3D-printed scaffold enhances whole-segment tracheal repair. Sci Rep 2017 Jul 12:7(1):5246. PubMed PMID: 28701742. Pubmed Central PMCID: PMC5507982. Epub 2017/07/14. eng.

Goldstein TA, Smith BD, Zeltsman D, Grande D, Smith LP. Introducing a 3dimensionally printed, tissue-engineered graft for airway reconstruction: a pilot study. Otolaryngol Head Neck Surg 2015 Dec;153(6):1001-1006. PubMed PMID: 26392025. Epub 2015/09/24. eng.

Graur D, Duret L, Gouy M. Phylogenetic position of the order Lagomorpha (rabbits, hares and allies). Nature. 1996 Jan 25;379(6563):333-335. PubMed PMID: 8552186. Epub 1996/01/25. eng.

Ho AS, Koltai PJ. Pediatric tracheal stenosis. Otolaryngol Clin N Am 2008;41(5): 999-1021, x. PubMed PMID: 18775347. Epub 2008/09/09. eng.

Hollister SJ, Flanagan CL, Zopf DA, Morrison RJ, Nasser H, Patel JJ, et al. Design control for clinical translation of 3D printed modular scaffolds. Ann Biomed Eng 2015 Mar;43(3):774-786. PubMed PMID: 25666115. Pubmed Central PMCID: PMC4407657. Epub 2015/02/11. eng.

Huang L, Wang L, He J, Zhao J, Zhong D, Yang G, et al. Tracheal suspension by using 3-dimensional printed personalized scaffold in a patient with tracheomalacia. J Thorac Dis 2016 Nov;8(11):3323-3328. PubMed PMID: 28066613. Pubmed Central PMCID: PMC5179458. Epub 2017/01/10. eng.

Jang YS, Jang CH, Cho YB, Kim M, Kim GH. Tracheal regeneration using polycaprolactone/collagen-nanofiber coated with umbilical cord serum after partial resection. Int J Pediatr Otorhinolaryngol 2014 Dec;78(12):2237-2243. PubMed PMID: 25465447. Epub 2014/12/04. eng.
Javia LR, Zur KB. Laryngotracheal reconstruction with resorbable microplate buttressing. Laryngoscope 2012 Apr;122(4):920-924. PubMed PMID: 22378653. Epub 2012/03/02. eng.

Kang N, Liu X, Guan Y, Wang J, Gong F, Yang X, et al. Effects of co-culturing BMSCs and auricular chondrocytes on the elastic modulus and hypertrophy of tissue engineered cartilage. Biomaterials. 2012 Jun;33(18):4535-4544. PubMed PMID: 22440049. Epub 2012/03/24. eng.

Karageorgiou V, Kaplan D. Porosity of 3D biomaterial scaffolds and osteogenesis. Biomaterials. 2005 Sep;26(27):5474-5491. PubMed PMID: 15860204. Epub 2005/04/30. eng.

Kaye R, Goldstein T, Grande DA, Zeltsman D, Smith LP. A 3-dimensional bioprinted tracheal segment implant pilot study: rabbit tracheal resection with graft implantation. Int J Pediatr Otorhinolaryngol 2019 Feb;117:175-178. PubMed PMID: 30579077. Epub 2018/12/24. eng.

Kim DY, Pyun J, Choi JW, Kim JH, Lee JS, Shin HA, et al. Tissue-engineered allograft tracheal cartilage using fibrin/hyaluronan composite gel and its in vivo implantation. Laryngoscope 2010 Jan;120(1):30-38. PubMed PMID: 19877186. Epub 2009/10/31. eng.

Klein AM, Graham VL, Gulleth Y, Lafreniere D. Polyglycolic acid/poly-L-lactic acid copolymer use in laryngotracheal reconstruction: a rabbit model. Laryngoscope 2005 Apr;115(4):583-587. PubMed PMID: 15805863. Epub 2005/04/05. eng

Kojima K, Bonassar L, Roy AK, Vacanti CA, Cortiella J. Autologous tissueengineered trachea with sheep nasal chondrocytes. J Thorac Cardiovasc Surg 2002 Jun;123(6):1177-1184. PubMed PMID: 12063466. Epub 2002/06/14. eng.

Kugler C, Stanzel F. Tracheomalacia. Thorac Surg Clin 2014;24(1):51-58. PubMed PMID: 24295659. Epub 2013/12/04. eng.

Kwon SK, Song JJ, Cho CG, Park SW, Kim JR, Oh SH, et al. Tracheal reconstruction with asymmetrically porous polycaprolactone/pluronic F127 membranes. Head Neck 2014 May;36(5):643-651. PubMed PMID: 23595895. Epub 2013/04/ 19. eng.

Law JX, Liau LL, Saim A, Idrus R. Tissue-engineered trachea: A review; 2016.

Lee JY, Park JH, Son SJ, Han M, Kim G, Kang SS, et al. Evaluation of immunosuppressive therapy use for tracheal transplantation with tracheamimetic bellows scaffolds in a rabbit model. Biomed Res Int 2017;2017: 5205476. PubMed PMID: 29226141. Pubmed Central PMCID: PMC5684528. Epub 2017/12/12. eng.

Lee YC, Hung MH, Liu LY, Chang KT, Chou TY, Wang YC, et al. The roles of transforming growth factor-beta(1) and vascular endothelial growth factor in the tracheal granulation formation. Pulm Pharmacol Ther 2011 Feb;24(1):2331. PubMed PMID: 21056681. Epub 2010/11/09. eng.

Lemaire A, Burfeind WR, Toloza E, Balderson S, Petersen RP, Harpole DH, Jr., et al. Outcomes of tracheobronchial stents in patients with malignant airway disease. Ann Thorac Surg 2005 Aug;80(2):434-437; discussion 7-8. PubMed PMID: 16039180. Epub 2005/07/26. eng.

Les AS, Ohye RG, Filbrun AG, Ghadimi Mahani M, Flanagan CL, Daniels RC, et al. 3D-printed, externally-implanted, bioresorbable airway splints for severe tracheobronchomalacia. Laryngoscope 2019 Aug;129(8):1763-1771. PubMed PMID: 30794335. Epub 2019/02/23. eng.

Lischke R, Pozniak J, Vondrys D, Elliott MJ. Novel biodegradable stents in the treatment of bronchial stenosis after lung transplantation. Eur J Cardio-thorac Surg 2011 Sep;40(3):619-624. PubMed PMID: 21334911. Epub 2011/02/22. eng.

Liu KS, Liu YH, Peng YJ, Liu SJ. Experimental absorbable stent permits airway remodeling. J Thorac Cardiovasc Surg 2011 Feb;141(2):463-468. PubMed PMID: 20884017. Epub 2010/10/05. eng.

Liu X, Sun H, Yan D, Zhang L, Lv X, Liu T, et al. In vivo ectopic chondrogenesis of BMSCs directed by mature chondrocytes. Biomaterials. 2010 Dec;31(36):94069414. PubMed PMID: 21056466. Epub 2010/11/09. eng.

Long CM, Conley SF, Kajdacsy-Balla A, Kerschner JE. Laryngotracheal reconstruction in canines: fixation of autologous costochondral grafts using polylactic and polyglycolic acid miniplates. Arch Otolaryngol Head Neck Surg 2001 May;127(5):570-575. PubMed PMID: 11346435. Epub 2001/05/18. eng.

Martinez-Ballarin JI, Diaz-Jimenez JP, Castro MJ, Moya JA. Silicone stents in the management of benign tracheobronchial stenoses. Tolerance and early results in 63 patients. Chest. 1996 Mar;109(3):626-629. PubMed PMID: 8617068. Epub 1996/03/01. eng.

Montgomery WW. T-TUBE TRACHEAL STENT. Archives of otolaryngology (Chicago, ill : 1960). 1965 Sep;82:320-1. PubMed PMID: 14327039. Epub 1965/ 09/01. eng.

Morrison R, Nasser H, Zopf D, Flanagan C, Wheeler M, Green G, et al. Biomechanical Properties and Effect on Tracheobronchial Growth of 3-D 
Printed Bioresorbable Airway Splints for Treating Tracheobronchomalacia 2014. S24 p.

Nicolli EA, Ghosh A, Haft S, Frank R, Saunders CJ, Cohen N, et al. IL-1 receptor antagonist inhibits early granulation formation. Ann Otol Rhinol Laryngol 2016 Apr;125(4):284-289. PubMed PMID: 26522467. Epub 2015/11/03. eng.

Park HS, Park HJ, Lee J, Kim P, Lee JS, Lee YJ, et al. A 4-Axis technique for threedimensional printing of an artificial trachea. Tissue Eng Regen Med 2018a Aug;15(4):415-425. PubMed PMID: 30603565. Pubmed Central PMCID: PMC6171658. Epub 2019/01/04. eng.

Park JH, Jung JW, Kang HW, Joo YH, Lee JS, Cho DW. Development of a 3D bellows tracheal graft: mechanical behavior analysis, fabrication and an in vivo feasibility study. Biofabrication. 2012 Sep;4(3):035004. PubMed PMID: 22914577. Epub 2012/08/24. eng.

Park JH, Park JY, Nam IC, Ahn M, Lee JY, Choi SH, et al. A rational tissue engineering strategy based on three-dimensional (3D) printing for extensive circumferential tracheal reconstruction. Biomaterials. 2018b Dec;185:276-283. PubMed PMID: 30261427. Epub 2018/09/28. eng.

Park JH, Yoon JK, Lee JB, Shin YM, Lee KW, Bae SW, et al. Experimental tracheal replacement using 3-dimensional bioprinted artificial trachea with autologous epithelial cells and chondrocytes. Sci Rep 2019 Feb 14;9(1):2103. PubMed PMID: 30765760. Pubmed Central PMCID: PMC6375946. Epub 2019/ 02/16. eng.

Propst EJ, Prager JD, Meinzen-Derr J, Clark SL, Cotton RT, Rutter MJ. Pediatric tracheal reconstruction using cadaveric homograft. Arch Otolaryngol Head Neck Surg 2011 Jun;137(6):583-590. PubMed PMID: 21690511. Epub 2011/06/ 22. eng.

Rehmani SS, Al-Ayoubi AM, Ayub A, Barsky M, Lewis E, Flores R, et al. Threedimensional-printed bioengineered tracheal grafts: preclinical results and potential for human use. Ann Thorac Surg 2017 Sep;104(3):998-1004. PubMed PMID: 28610885. Epub 2017/06/15. eng.

Rosso F, Giordano A, Barbarisi M, Barbarisi A. From cell-ECM interactions to tissue engineering. J Cell Physiol 2004 May; 199(2):174-180. PubMed PMID: 15039999. Epub 2004/03/25. eng.

Rotter N, Ung F, Roy AK, Vacanti M, Eavey RD, Vacanti CA, et al. Role for interleukin 1alpha in the inhibition of chondrogenesis in autologous implants using polyglycolic acid-polylactic acid scaffolds. Tissue Eng 2005 Jan-Feb;11(1-2):192-200. PubMed PMID: 15738674. Epub 2005/03/02. eng.

Schwarz S, Koerber L, Elsaesser AF, Goldberg-Bockhorn E, Seitz AM, Durselen L, et al. Decellularized cartilage matrix as a novel biomatrix for cartilage tissueengineering applications. Tissue Eng A 2012 Nov;18(21-22):2195-2209. PubMed PMID: 22690787. Epub 2012/06/14. eng.

Sing SL, Wang S, Agarwala S, Wiria F, Ha MH, Yeong WY. Fabrication of titanium based biphasic scaffold using selective laser melting and collagen immersion; 2017.

Sprecher RC. Single-stage laryngotracheal reconstruction using bioabsorbable miniplates. Laryngoscope 2010 Aug;120(8):1655-1661. PubMed PMID: 20564734. Epub 2010/06/22. eng.

Tappa K, Jammalamadaka U, Weisman JA, Ballard DH, Wolford DD, PascualGarrido C, et al. 3D printing custom bioactive and absorbable surgical screws, pins, and bone plates for localized drug delivery. J Funct Biomater 2019 Apr 1;10(2). PubMed PMID: 30939719. Epub 2019/04/04. eng.

Townsend JM, Ott LM, Salash JR, Fung KM, Easley JT, Seim HB, 3rd, et al. Reinforced electrospun Polycaprolactone nanofibers for tracheal repair in an in vivo ovine model. Tissue Eng A 2018 Sep;24(17-18):1301-1308. PubMed PMID: 29580173. Pubmed Central PMCID: PMC6150933. Epub 2018/03/28. eng.

Tsao CK, Ko CY, Yang SR, Yang CY, Brey EM, Huang S, et al. An ectopic approach for engineering a vascularized tracheal substitute. Biomaterials. 2014 Jan; 35(4):1163-1175. PubMed PMID: 24239301. Epub 2013/11/19. eng.

Vacanti CA, Paige KT, Kim WS, Sakata J, Upton J, Vacanti JP. Experimental tracheal replacement using tissue-engineered cartilage. J Pediatr Surg 1994 Feb;29(2): 201-204; discussion 4-5. PubMed PMID: 8176592. Epub 1994/02/01. eng.

Wain JC, Jr. Postintubation tracheal stenosis. Semin Thorac Cardiovasc Surg 2009 Fall;21(3):284-289. PubMed PMID: 19942129. Epub 2009/11/28. eng.

Wang S, Zhang H, Zhu L, Zhen J, Liu J, Xu Z. Surgical management of congenital tracheal stenosis associated with tracheal bronchus and congenital heart disease. Eur J Cardio-thorac Surg 2016 Apr;49(4):1201-1206. PubMed PMID: 26374867. Epub 2015/09/17. eng.

Wu W, Feng X, Mao T, Feng X, Ouyang HW, Zhao G, et al. Engineering of human tracheal tissue with collagen-enforced poly-lactic-glycolic acid non-woven mesh: a preliminary study in nude mice. Br J Oral Maxillofac Surg 2007 Jun; 45(4):272-278. PubMed PMID: 17097777. Epub 2006/11/14. eng.
Yener M, Acar GO, Cansiz H, Oz B, Cigerciogullari E, Seymen O. Use of titanium mesh in laryngotracheal reconstruction: an experimental study on rabbits. European archives of oto-rhino-laryngology : official journal of the European Federation of Oto-Rhino-Laryngological Societies (EUFOS) : affiliated with the German Society for Oto-Rhino-Laryngology - Head and Neck Surgery. 2010 Aug;267(8):1247-53. PubMed PMID: 20069310. Epub 2010/01/14. eng.

Zopf DA, Flanagan CL, Wheeler M, Hollister SJ, Green GE. Treatment of severe porcine tracheomalacia with a 3-dimensionally printed, bioresorbable, external airway splint. JAMA Otolanyngol Head Neck Surg 2014 Jan;140(1):66-71. PubMed PMID: 24232078. Pubmed Central PMCID: PMC4429780. Epub 2013/11/16. eng.

\section{Publisher's Note}

Springer Nature remains neutral with regard to jurisdictional claims in published maps and institutional affiliations.
Ready to submit your research? Choose BMC and benefit from:

- fast, convenient online submission

- thorough peer review by experienced researchers in your field

- rapid publication on acceptance

- support for research data, including large and complex data types

- gold Open Access which fosters wider collaboration and increased citations

- maximum visibility for your research: over $100 \mathrm{M}$ website views per year

At BMC, research is always in progress.

Learn more biomedcentral.com/submissions 